\title{
The international emergence of rural criminology: Implications for the development and revision of criminological theory for rural contexts ${ }^{1}$
}

Joseph F. Donnermeyer

Professor Emeritus

School of Environment and Natural Resources

The Ohio State University

UNITED STATES OF AMERICA

Contact author - Joseph F. Donnermeyer: donnermeyer.1@gmail.com; +1 6145824710

\begin{abstract}
The objectives of this article are two-fold. First, it briefly reviews the historical development of rural criminology and rural crime studies. It argues that continued development of rural criminology requires two fundamental things: (i) rural criminology must avoid dichotomies both old (ex., gemeinschaft vs. gessellschaft) and new (ex., global south vs. global north) because dichotomies have great potential to retard development of a comparative scholarship about crime and criminal justice issues across the diversity of rural localities found throughout the world; and (ii) rural criminology must be inclusive, embracing an international network of scholars from every region of the world, regardless of arbitrary grid lines on a globe. Second, this article argues that rural crime scholarship must develop frameworks from which theories of the "middle range" (Merton, 1957) can be developed, and in turn, theories most suited to the international development of rural criminology should allow for comparisons across diverse research settings and facilitate the synthesis of rural literatures about crime and criminal justice. Rural crime studies should continue to move toward being more theoretically diverse, more critical by linking the local to larger social forces (Mills, 1959; Young, 2011; Donnermeyer \& DeKeseredy, 2014), more international in scope, and more self-aware of its history and its future. To this end, the article describes a framework for understanding rural communities (Liepins, 2000) and explains how three rural-based "middle range" criminological theories already fit within the fundamental elements of this framework. The article concludes by urging rural scholars to develop additional frameworks from which middle range theories of rural crime and criminal justice issues can be launched.
\end{abstract}

Keywords: rural criminology, internationalization, community, place and crime, primary socialization theory, civic community theory, male peer support model for violence against women 
International Journal of Rural Criminology, Volume 5, Issue 1 (November), 2019

\section{Introduction}

In June 2017, the first 'special issue' of the International Journal of Rural Criminology (IJRC) was published. Its focus was on agricultural crime (Bunei, 2017). The special issue editor was from Kenya and the articles themselves included the victimization experiences of farmers from research conducted in Australia, England, Ethiopia, Kenya and the United States. Each article incorporated literature on farm crime from around the world, but paid particular attention to the localized context of agricultural victimization.

Somehow, no matter how international in orientation some attempts to critique and revise criminological theory and research claim to be, the ones that possess the most potential to advance scholarship and be more than simply another expression of opposition to mainstream theories are those that recognize, ironically, the importance of the local. In fact, a strong case can be made that without the local, the advancement of almost any kind of criminological theory is impossible (Donnermeyer, 2016a), because it is there that real people experience the anxieties and insecurities associated with crime and injustice, and it is there that some people learn and then actualize their criminal behaviors. Perhaps this is nowhere more true than in the criminological subfield of rural criminology.

Why is the local so essential to a rural criminology? The reason is simple - rural places around the world are so many and so diverse. Take, for example, articles from the special issue on farm crime in IJRC. Most of those articles shared the same insight about the more predatory nature of farm crime today when compared to the past, but always, a predation based on probabilities of victimization that varied according to the characteristics of diverse local contexts, including the size of an agricultural operation, topography, and the ability of thieves to move stolen property to a place where they could convert it to cash (mostly in the nearest city), among others.

Three examples will suffice to illustrate the link of local context to larger economic and social forces. On the island of Anglesey in Wales, quad bikes are frequently stolen (Holmes \& Jones, 2017). These bikes are easy to transport out of the area and converted to cash either through sales in an underground market or through parts when disassembled. As Holmes and Jones (2017) remind readers: "While Anglesey is a rural county in Wales it is not a remote location". Harkness (2017) presents the insights of Agricultural Liaison Officers in the Australian state of Victoria. He observes, based on their views of farm crime, that in older times, farmers harvested their own crops. In newer times, many farmers rely on contractors who hire truckers to transport the grain. In turn, some of these truckers have time to study a farm's layout and then steal some of the very grain they have been hired to take to market. Often, the purloined grain is sold in another state, which is relatively easy to do given the quality of highways in Australia. Finally, there is the case of crop theft in the highlands of Ethiopia (Chiwona-Karltun, Lemenih, Tolera, Berisso \& Karltun, 2017). The authors found in particular that fava bean theft is now so extensive it can no longer be considered petty in nature, that is, associated with someone who is hungry. The motives are now commercial, that is, to make money, which is also the trend of farm theft in Kenya and most other regions of the world (Bunei \& Barasa, 2017). For example, no longer is it merely fava beans stolen to satisfy the hunger of a poor person, but a much greater volume of theft that threatens the very economic well-being of the producers. 


\section{The international emergence of rural criminology: Implications for the development and revision of criminological theory for rural contexts - Donnermeyer}

Indeed, rising theft has forced many farmers in Ethiopia to shift to crops that cannot be directly consumed, as fava beans can, resulting in increased use of fertilizers, more farm debt, and water pollution from the runoff of fertilizers.

The point of reviewing these studies is to highlight the link between rural localities and larger rural realities associated with global economies, transportation systems linking farming areas with urban centers, and changing motives for agricultural theft, namely, a stronger economic motive today. This is what C.W. Mills (1959) meant when he proposed the idea of the Sociological Imagination and what Jock Young (2011) meant in The Criminological Imagination. To theorize about sociological phenomena like crime and justice without maintaining a firm focus on the localized experiences of rural peoples will likely be ineffective, ignoring diversities and by doing so, ironically, missing out on larger patterns of crime that link the local and the global. As Jones, MacLean and Young (1986) pointed out over 30 years ago, the ability to understand crime from national surveys is limited. It requires a localized examination of crime, both qualitatively and quantitatively, to understand how the connection between local expressions of crime and social structure.

Hence, dichotomies will not work, whether they are the old, hackneyed ones like 'rural' versus 'urban' and 'gemeinschaft' versus 'gesellschaft', or newer ones like the 'global south' versus the 'global north' Just as Jock Young (2011) criticized the primacy of data and analytical techniques to the sacrifice of sound conceptual and theoretical development, derisively calling this syndrome "abstracted empiricism", so too the crutch of dichotomies represents forms of "abstracted theorism" because the intellectual connection between local context and larger social structural forces (all of which can be measured either quantitatively or qualitatively or both, and then tested) is lost.

The recent emergence of rural criminology and its future development, both theoretically and empirically, depends on maintaining an international focus that provides conceptual bridges for the synthesis of diverse studies from the hundreds of thousands of rural places in societies around the world, regardless of their economic, social and cultural compositions, and no matter the region of the world in which they are located.

\section{A short history of rural criminology}

Figure 1 below is adopted and expanded from the introductory chapter to the Routledge International Handbook of Rural Criminology (Donnermeyer 2016b, p. 4). It is retitled here as a "Concise Chronology of Rural Criminology", and the information in it includes additional detail about past events, and adds in developments since 2016. However, the anchored conclusions at the top and bottom of "selected highlights" are the same. Simply, rural criminological scholarship for many decades was scattered and atheoretical. I should add, almost all of it was from the United States.

It was not until the mid-1990s that rural criminology scholarship became self-aware, and much credit for this can be given to Weisheit, Wells and Falcone's book, first published in 1996, titled Crime and Policing in Rural and Small-town America (followed by a second edition published in 1999 and a third edition published in 2006). This book provided the first synthesis 
of a very scattered literature, even though focused almost exclusively on the United States. Later, however, one can see Weisheit's skill for gathering literature in an article he wrote for the International Journal of Rural Criminology, titled "Rural Crime from a Global Perspective." This article, published in Volume 3, Issue 1 (Weisheit, 2016) of IJRC includes 121 rural crime articles about some place other than the United States, even though on some, there is an American author. The largest number focus on rural crime in Australia.

Australia's influence on rural criminology scholarship was certainly welcome because, as already mentioned, for rural criminology to grow and be both theoretically and empirically vibrant, it must by nature be international in scope and perspective. Even though one can argue that the similarities between the two countries, both settler societies, are so great as to create only a modest international expansion of theoretical and empirical scholarship about rural crime, it was a start.

The chronology in Figure 1 is anchored at the bottom by a statement that stands in sharp contrast to the one at the top. It says: " $21{ }^{\text {st }}$ century work - more theoretically diverse, more critical, more international, and more self-aware". Perhaps the most important word in that statement is "more", and serves as a reminder that rural criminology's scholarly development has a very long way to go. One event to sustain this direction for rural criminology was made by Donnermeyer and DeKeseredy (2014), whose monograph on "Rural Criminology" was informed greatly by left realism.

Yet, the amount of progress, especially toward a more internationalized rural criminology, one that extends beyond the borders of Australia, Canada, Great Britain and the United States (the 'big four', which I purposively mean as a pejorative), is beginning to happen. Three examples are a conference held in Stockholm, Sweden in 2014, with a subsequent special issue published in the Journal of Rural Studies (Ceccato, 2015), the organization of sessions at the European Society of Criminology in 2017 and 2019, and the first ever rural crime conference in Africa, held in a suburb of Pretoria in 2017.

One goal of the Routledge International Handbook of Rural Criminology, published in 2016 (Donnermeyer, 2016b) was to go beyond the 'big four' in regard to both authors and foci. Regrettably, that goal was only partially successful. Of the 42 chapters, only two were about rural China, only three considered rural crime in Africa, and sadly, only a single chapter on a South American country (Brazil). As often as not, the authors were from the 'big four', but working on topics related to rural crime in the 'non-big four' countries. Missing completely from the handbook were chapters focused on countries of Southeast Asia, Eastern Europe, and the Middle East (Donnermeyer, 2016c).

It is possible that little or no rural research was ever completed in those areas. However, it is also possible that both theory and research on crime in many rural regions of the world is so obscure as to be virtually unknown. Sometimes, the barrier is language. For example, Meng (2018) makes a compelling case that there is "lost" literature about crime in rural China because it is in Mandarin, not English. One might argue that this is a very western-centric point of view. Perhaps scholarship from the 'big four' is what is really lost because it is in English only, not Mandarin. That argument, however, quickly becomes nonsensical once it is recognized that no 


\section{The international emergence of rural criminology: Implications for the development and revision of criminological theory for rural contexts - Donnermeyer}

single language should be given linguistic primacy, therefore, who is to say that Rotokas (White, n.d.), spoken by an estimated 4,000 inhabitants of Papua New Guinea, is not the superior language to be used for all rural criminological scholarship? Of course, that is a mere rhetorical question. There is the practical matter that except for a rare rural crime scholar of high perspicacious parlance, learning more than a handful of languages leaves no time for actual research and theorizing. English is the primary language for the moment, due to its spread as a second language throughout the world, and its diffusion is associated with over two centuries of British (and later, American) forms of colonialism and of the development of market-based economies almost everywhere (which we call 'globalization') during that time.

Nonetheless, rural criminology cannot ever claim to be international in its empirical and theoretical scope if there is no basis on which scholarship from the diverse rural places of the world, and from the billions of people who live there in millions of villages and small communities embedded in thousands of distinctive cultures can be pulled together into a more cohesive body of knowledge. 


\section{Figure 1: A Concise Chronology of Rural Criminology}

\section{Sources of Scholarship in Rural Criminology}

occasional rural-focused research, mostly on rural juvenile delinquency, violent crime, and rural policing by criminologists and rural sociologists with little crosss-referencing

crime impact assessment - energy boomtowns

first wave of agricultural crime studies - mostly U.S.

substance use, production and trafficking in the rural context

rural places and crime: homicide studies, regional culture of violence studies, social disorganisation theory

theory tested in rural places

research and theory on

violence against rural women

development of "civic community" theory $\&$ continuing empirical work on community and crime

the emergence of "Green

Criminology" and its intersectionality with rural criminology

new wave of crime impact assessments and energy development in Australia and elsewhere

new wave of agricultural crime studies - Africa, Australia, United Kingdom \& elsewhere

renewed focus on rural policing and prisoner re-entry//renewed focus on rural substance use, production and trafficking//increasing links between rural law and rural criminal justice scholarship

\section{Selected Highlights}

early work - scattered, theory-less, with little synergy

1931: Sorokin, Zimmerman \& Galpin: Systematic Sourcebook in Rural Sociology, including chapter on rural crime in various countries around the world 1933: Smith - Rural Crime Control

1940s: Clinard \& Vold (Sutherland awardees from the American Society of Criminology) - comparative work on rural \& urban crime

1964: Chambliss (President of ASC, 1988) - publication in Social Problems "A Sociological Analysis of the Law of Vagrancy" - likely the first rural critical criminology study

1973: Dinitz (President of ASC, 1971) - publication in Criminology - "Progress, Crime and the Folk Ethic: Portrait of a Small Town"

1978: National Rural Crime Prevention Center (NRCPC) founded, The Ohio State University, with conference on "Rural Crime" (sponsored by NRCPC) in 1980 1982: Carter, Phillips, Donnermeyer \& Wurschmidt (eds) Rural Crime: Integrating Research and Prevention

1992: Edwards (ed) Drug Use in Rural American Communities, and rural work on substance use at the Tri-Ethnic Center for Prevention Research, Colorado State University (CSU) and elsewhere

1996: Weisheit, Falcone \& Wells: Crime and Policing in Rural and Small-town America $\left(1^{\text {st }}\right.$ edition) $\left(3^{\text {rd }}\right.$ edition published in 2006)

1997: Robertson, Sloboda, Boyd, Beatty, \& Kozel (eds.), Rural Substance Use: State of Knowledge. National Institute of Drug Abuse publication.

1998: development of primary socialization theory (mostly rural) through a series of 4 articles in Substance Use and Misuse by Oetting and associates from CSU // Websdale: Rural Woman Battering and the Justice System: An Ethnography 1999: Dingwall \& Moody: Crime and Conflict in the Countryside // Conference-

"Crime in Rural Communities" at University of New England, NSW - organised by Jobes \& Barclay and co-sponsored by the Australian Institute of Criminology 2004: Chakraborti and Garland (eds): Rural Racism

2006: Hogg \& Carrington: Policing the Rural Crisis // $2^{\text {nd }}$ Conference -"Crime in Rural Communities" - at University of New England, NSW - organised by Barclay 2007: Barclay, Donnermeyer, Scott \& Hogg (eds): Crime in Rural Australia // first attempt to start a rural criminology journal - The International Journal of Rural Crime 2008: special rural crime issue in Southern Rural Sociology // Lee: "Civic community theory in the hinterland: toward a theory of rural social structure and violence", in Criminology (rural-based theory of crime \& place)

2009: DeKeseredy \& Schwartz: Dangerous Exits: Ending Abusive Relationships in Rural America (includes rural-based "male peer support model of separation and divorce sexual assault") // Wendt: "Domestic Violence in Rural Australia"

2011: $1^{\text {st }}$ issue of International Journal of Rural Criminology (IJRC) // Garriott: Policing Methamphetamines // Mawby \& Yarwood (eds): Rural Policing \& Policing the Rural

2014: Donnermeyer \& DeKeseredy: Rural Criminology // special rural crime issue in Critical Criminology, edited by Donnermeyer, Carrington \& DeKeseredy // Conference - "Rural Crime and Community Safety" conference - at Royal Institute of Technology, Stockholm, organised by Ceccato

2015: special rural crime issue in Journal of Rural Studies, edited by Ceccato // Ceccato: Rural Crime and Community Safety // European Society of Criminology - 2 sessions on "rural policing and crime", organised by Harkness \& Wooff // Saunders: Whispers from the Bush: The Workplace Sexual Harassment of Australian rural women

2016: Donnermeyer (ed.): International Handbook of Rural Criminology // Irwin \& Umemoto, Jacked Up and Unjust: Pacific Islander Teens Confron Violent Legacies; Shukla: Methamphetamine: A Love Story // Harkness, Harris \& Baker: Locating Crime in Context and Places: Perspectives on Regional, Rural and Remote Australia

2017: special issue on agricultural crime, IJRC. E. Bunei (guest ed.) // "International Conference on Rural Crime" - at Centurion, South Africa (Pretoria) - organised by Clack and Minnaar (University of South Africa, College of Law). Special issue to be published in 2019 in Acta Criminologica from conference papers // Ruddell: Oil, Gas, and Crime: The Dark Side of the Boomtown

2018: Gray \& Hinch (eds.), A Handbook of Food Crime // Inaugural meeting of the Division of Rural Criminology at the American Society of Criminology annual meeting

in Atlanta // November conference - "Rural Crime and the Law" - at University of New England, NSW - organised by Barclay and the UNE School of Law

2019 and beyond: Donnermeyer, The Criminology of Food and Agriculture // Routledge monograph series in Rural Criminology begins in 2019 // February, 2019 -- Conference - "Understanding Crime and Rural Communities" - at Federation University, Gippsland campus, organised by Harkness, Smith, Strating \& White // new Centre for Rural Criminology, University of New England, NSW, director, K. Mulrooney // special rural crime issue in Crime Prevention \& Community Safety, edited by Hollis // special issue on rural crime from conference papers in IJRC from the Harkness et al. conference // the International Society for the Study of Rural Crime (ISSRC) founded in April // session on rural crime for the European Society of Criminology // at least a dozen paper sessions and roundtables planned for the November annual meeting of ASC, including a co-sponsored roundtable by the Association of Chinese Criminology and Criminal Justice and the Division of Rural Criminology

$21^{\text {st }}$ century work - more theoretically diverse, more critical, more international. and more self-aware 


\section{The international emergence of rural criminology: Implications for the development and revision of criminological theory for rural contexts - Donnermeyer}

\section{Building a theory of place for rural criminology}

Words are important. They convey essential meanings that describe, interpret and conclude. For much of its history, the science of criminology ignored 'rural crime.' The words meant nothing of importance to a general understanding of crime in terms of offending behaviour, victimisation, perceptions of citizens, and issues related to police, courts and other justice agencies. (Donnermeyer, 2007, p. 3).

This statement was made for the lead article in the first attempt to start a rural journal - The International Journal of Rural Crime. A second issue was never published. ${ }^{2}$ The quote expresses a dichotomy - rural versus urban - that was useful a decade ago to highlight the extreme neglect of rural crime by mainstream criminology, both in the United States and elsewhere. Now that rural criminology is developing, its utility is diminished, if not completely useless.

There are other worn-out dichotomies besides rural versus urban, such as gemeinschaft (community) and gesellschaft (society) by the nineteenth century theorist, Ferdinand Tönnies (1955). Gesellschaft or society was assumed by most of the criminological community to mean the opposite of rural or rurality, which was associated with gemeinschaft or community. Likewise, Louis Wirth (1938) wrote about urbanism as a way of life, and even though in this article he recognized that there is considerable variation in the contexts of places, both large and small, almost all criminologists simply assumed his rendition of the dimensions of urbanism were the opposite of those associated with rural life.

Both the work of Tönnies (1955) and Wirth (1938) was foundational to the development of criminology vis-à-vis the Chicago School of Sociology (Lilly, Cullen \& Ball, 2015, pp. 39-41), which in turn led to another dichotomy with limited utility, namely, social disorganization versus social organization. Fallaciously, the concept of disorganization not only became associated with the conditions of high crime places, but with the concepts of gesellschaft (Tönnies, 1955) and urbanism (Wirth 1938) more generally. In turn, all three - social organization, gemeinschaft, and rurality - pretty much came to mean the same thing (Donnermeyer \& DeKeseredy, 2014), namely, little crime and little theoretical and empirical significance to the criminological community at-large.

Constructions of dichotomies continue today. A prominent one is the 'global south' versus the 'global north' (Carrington, Hogg, Scott \& Sozzo, 2018), and with it a set of other tropes, such as inside versus outside the "metropole" (Carrington, Hogg \& Sozzo, 2016); the 'core' versus the 'periphery'; and the less frequently used but older and more generic distinctions of both occidentalism versus orientalism and western-centric versus everywhere else.

Dichotomies, especially of an oppositional nature, can be useful for calling attention to areas of neglected scholarship and to the need to re-direct, renew and even overhaul scholarship before it is too heavily colonized by a single theory or school of thought. However, as Moosavi (2019, p. 263) pointed out in a recent critique of southern criminology, the 'global south' versus 'global north' dichotomy is both vague and glosses over vast diversities within societies both south and north of the equator. For example, various contributors to the Carrington et al. (2018) tome use southern to imply areas that are politically, culturally and sociologically tangential and 
outside power centers. Indeed, there is an uneven distribution of resources of all kinds when comparing localities within any society (and between societies around the world), but such gross generalities do little to advance our understanding of place and crime. Further, just as an earlier generation of scholars misinterpreted Wirth's (1938) discussion of urbanism as associated only with city environments, so too, it would not take much for contemporary devotees of dichotomies to misguidedly pair up 'periphery' and 'rural' in ways that are retrocessive to the development of rural criminology.

It would seem that a criminology of the global south should have much potential for advancing rural criminological scholarship because countries that straddle or are south of the equator (to use a strictly geographic demarcation) possess much larger (proportionately) rural populations and are more likely to be areas with long histories of colonial and post-colonial exploitation by countries from the north (Donnermeyer, 2018). But, so long as it is expressed in dichotomous terms, without elucidation of its theoretical premises or of healthy theoretical critique and debate (Moosavi, 2019), the limitations of a global southern criminology for informing rural criminological scholarship are insurmountable. What remains, ironically, is the greater potential of rural criminology to advance southern criminology because as rural criminology develops, more research in countries included under the 'global south' rubric will take place (Donnermeyer, 2018).

What is the alternative? The answer: go nominal! Forget dichotomies entirely and seek out a theory of place and crime that includes elements universally found in localities around the world, regardless of country, region and even population size (even though the focus of this paper is on the advancement of rural criminology).

To go nominal rather than global, one must seek to develop a framework that can account for rural diversity without glossing over rural heterogeneity, and that can help rural scholars develop rigorous theories of the "middle-range" (Merton, 1957) on specific topics. Fortunately, a framework is already available, although I would not claim it should be the only one. It is by a New Zealander who is not a criminologist, and the framework itself was not developed for criminologists, but for rural sociologists. It is an article from the Journal of Rural Studies (2000) by Ruth Liepins titled 'New energies for an old idea: reworking approaches to 'community' in contemporary rural studies". Liepins (2000, pp. 26-27) couches her approach as post-modernist in order to draw from scholarship that emphasizes diverse "knowledges", that includes "broader social thought" which consider "...debates in feminist, postcolonial and post structural works..." (p. 27), and pays greater attention to critical work about "...debates surrounding the interconnections (and struggles) between identity, space and place...”.

To this end, Liepins (2000, p. 30) describes a community as a locality in which there is both "temporally and locationally specific terrains of power and discourse", and in which “...people within a 'community' can be individually or collectively treated as diversely positioned in various categories such as 'groups', 'classes', and 'networks"'. This latter statement is both in agreement with and in opposition to older misconceptions about crime, rurality and place (Donnermeyer \& DeKeseredy, 2014). It assumes that expressions of human behavior, including crime, are based on forms of social organization or networks rather than social disorganization, yet, it recognizes the simultaneity of an individual's participation in 
The international emergence of rural criminology: Implications for the development and revision of criminological theory for rural contexts - Donnermeyer

multiple networks that can be misinterpreted as a form of social disorganization that was previously assumed to be a more prominent feature of places with larger and denser populations. No such assumption is made in Liepins' (2000) framework, however. Multiple networks are a reality without any necessary assumptions about causality, hence, representing forms of social organization that may simultaneously constrain some crimes from occurring at a place even as these very same networks may facilitate the commission of other offenses.

\section{Figure 2: Liepins' (2000) schematic for the fundamental elements of places $^{3}$}

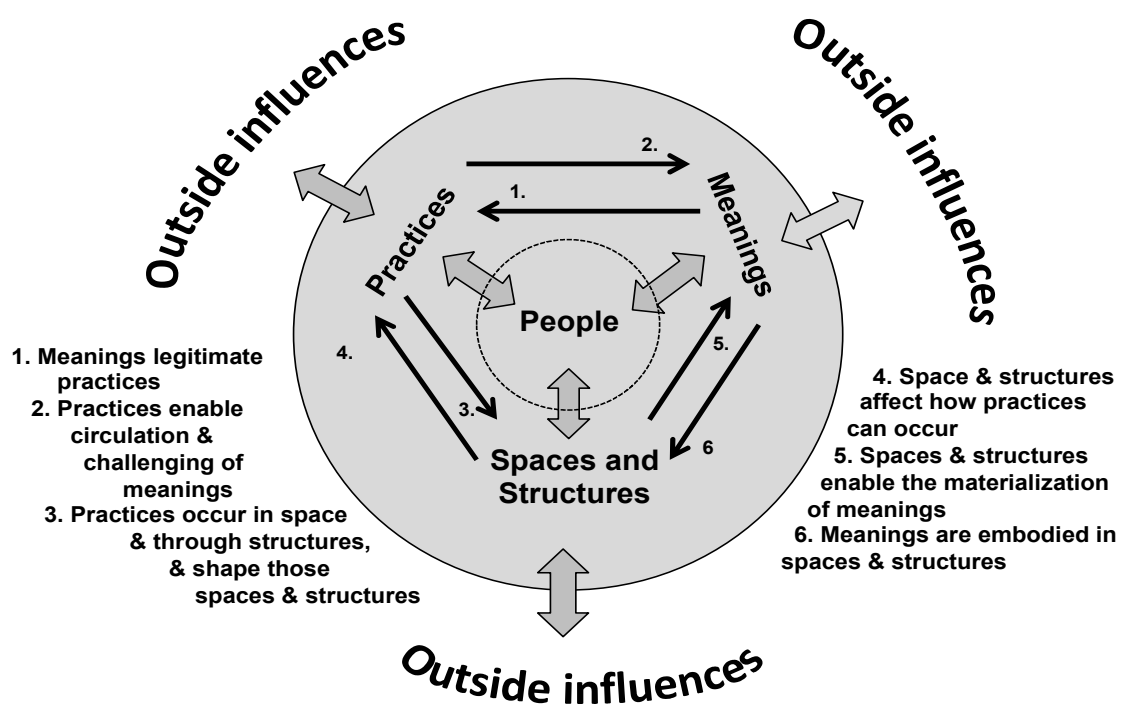

Liepins (2000, p. 30) sees a two-way relationship amongst the three key elements of a place, namely, meanings, practices and spaces/structures (Figure 2). Hence, "meanings legitimate practices", while practices "enable the circulation and challenging of meanings". In turn, "practices occur in spaces and through structures, and shape those spaces and structures" and spaces and structures "affect how practices can occur" (Liepins, 2000, p. 30). Finally, spaces and structures "enable the materialization of meanings" and meanings "are embodied in spaces and structures" (Liepins, 2000, p. 30).

There is one final dimension to the work of Liepins (2000). Through each of the three elements come possible influences or sources of change from the outside. Hence, her concept of community is not intended as a closed system, but rather as a dynamic system of human interaction embedded in a localized context, but affected by larger social structural change.

\section{The rural roots of three criminological theories of the "middle range"}

There already are three criminological theories that have strong rural roots. It is likely there are others, but these three each fit within Liepins' (2000) conceptualization of place and crime, even though none were aware of her work at the time their authors first developed these ruralbased theories. 


\section{Primary socialization theory}

The earliest and first was the 'primary socialization theory', which came out of the TriEthnic Center for Prevention Research at Colorado State University. Its purpose was to provide an understanding of substance use, especially among adolescents, at smaller places (Oetting, Donnermeyer \& Deffenbacher, 1998). The name "Tri-Ethnic" derives from its focus on rural populations of the western region of the United States, specifically, white, Hispanic and Native American.

This theory, social psychological in perspective, assumes that young people become enmeshed in either drug-using or non-drug-using networks of close friends based on a young person's relative adjustment in schools (especially with teachers and coaches) and their relationship with other members of their immediate family. These assumptions resonate with aspects of both social control theory and the theory of differential association (Lilly, Cullen \& Ball, 2015).

The causal logic of primary socialization theory is shown in Figure 3. Despite pre-dating Liepens' (2000) work, it is remarkably similar. It not only allows room for community-level characteristics and outside influences, it assumes the self is connected to multiple networks that define attitudes and behaviors regarding both experimental and regular substance use/misuse. Even though it considers community-level characteristics, as does social disorganization theory (such as poverty and population turnover), it is completely unlike social disorganization theory because it sees these larger social forces as the context in which forms of social organization either foster or hinder rural adolescent substance use. Hence, adolescent association with peers may either facilitate or constrain substance use, depending on whether or not close friends use or experiment, and the degree of a young person's adjustment in school and bonding with parents. Of particular significance, it accounts for an additional layer of context because it also considers important parental involvement in school and how much close friends of a young person are also embedded in a school's culture. Furthermore, it considers the extent to which parents know and interact with their teenage children's friends. There is no social disorganization to be found anywhere in this theory, despite its consideration of community-level factors that might change all of the human arrangements described in this paragraph.

In essence, therefore, there are three levels that define a localized context, according to Primary Socialization Theory. First, there in the individual or self and that individual's relationship with three key groups - parents, schools, and peers. There is a second level of how a young person's friends, family and school interact with each other. Finally, there is a third level that conditions or mediates the relationships of the first two levels, namely, both community characteristics and larger social structural factors that define the social and economic conditions of specific places. 
The international emergence of rural criminology: Implications for the development and revision of criminological theory for rural contexts - Donnermeyer

Figure 3: Causal schematic of Primary Socialization Theory ${ }^{4}$

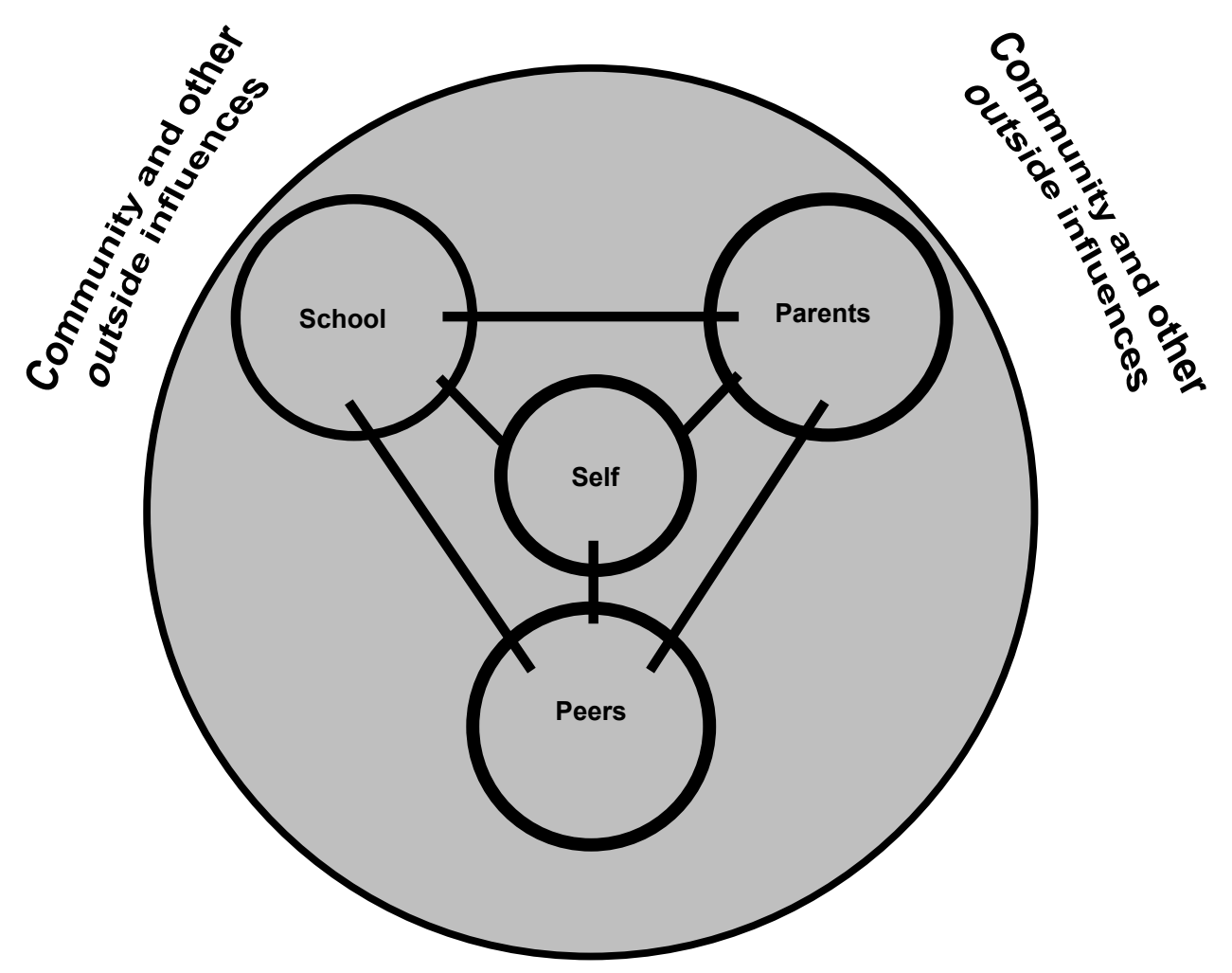

\section{Civic community theory}

A second theory with strong rural roots is the work of Matthew Lee (2008) on "civic community". This theory is based, like Liepins (2000) conceptualization of community, on previous work in rural sociology, not criminology. However, Lee (2008) applies it to the quantitative analysis of violent crime rates in rural communities in the United States, arguing that the strength of the local ecology of a community through such indicators as voter participation, locally owned businesses, and active participation in church groups can explain variance in crime rates. Lee (2008, p. 449) took pains to distinguish his theory "from other, more crime-specific theories, such as the systemic social disorganization model...". In this sense, his theorizing was in the right direction, and one advocated in this article. That is, start first with a theory of place, and then examine crime patterns, rather than the other way as assumed by the founders of the Chicago School of Sociology many decades ago, and those who abide by the tenets of social disorganization theory today, which wrongly is to squeeze a theoretical framework of place to crime. 


\section{Figure 4: Schematic of Civic Community Theory ${ }^{5}$}

\section{Control Variables}

Poverty
Unemployment
Percent, female-headed
$\quad$ households
High-school dropouts
Percent black
Adult-child ratio
Logged total population

\section{Civic Community Indicators}

Nonmigration (living in same county 5 years prior)

Living in same house ( 5 years prior)

Home ownership (percent)

Congregations per 1,000 population

Civically engaged religious denomination

Voter turnout

Family farms per 1,000 population

Small manufacturing ( $\leq 20$ employees)

Percent of labor force self-employed

Percent of labor force working at home

Lee's (2008) theory has similarities with the systemic version of social disorganization theory because it considers measures of the local ecology or conditions inside of a place. The systemic version of social disorganization theory (Bursik, 1999) was in part an attempt to improve upon the structural antecedent model, which largely relied on various census measures as proxies for social disorganization. Hence, the proportion of single parent households in a community would be used as an example of disorganization and presumed related to higher rates of crime, without any particular understanding about the actual causal connections between the two, and obviously, without any direct testing of those connections. This is akin to correlating the sequence of sun spots to stock market averages and if a correlation is found, then causality is claimed. Lee (2008) set out to discern just how indicators of the strength of the local ecology of place affects crime rates, after controlling statistically for the effects of various social structural antecedents, which he treats as control variables. This causal logic can be seen in Figure 4.

\section{Feminist / male peer support model of separation and divorce sexual assault}

A third theory with extensive rural roots and one that is also compatible with Liepins' (2000) conceptualization of community is the feminist / male-peer support theory for violence against women by DeKeseredy and Schwartz (2009). Recognizing the highly patriarchal nature of some societies, or of regions with a single society, and of misplaced beliefs and values associated with women as the reproductive property of men, the theory sees a combination of threats to masculinity and patriarchal control due to larger social forces (especially those that affect economic change and therefore the availability of jobs), peer networks that support male dominance and rationalize the use of violence against women, and key events, such as a separation or divorce, as the contexts in which women specifically become the victims of violence at rural localities, as instigated by their partners. The relationship of the factors involved in male peer support theory is shown in Figure 5. 


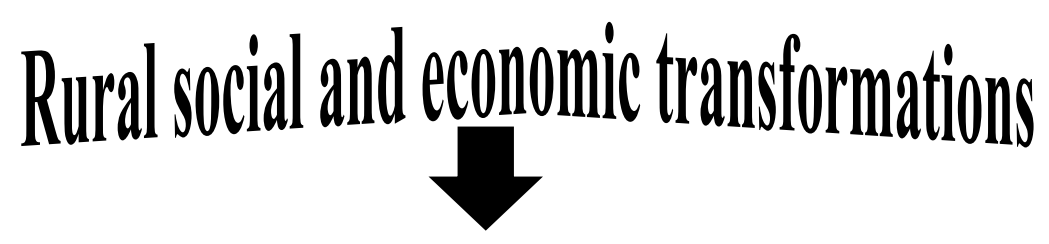

Societal patriarchy

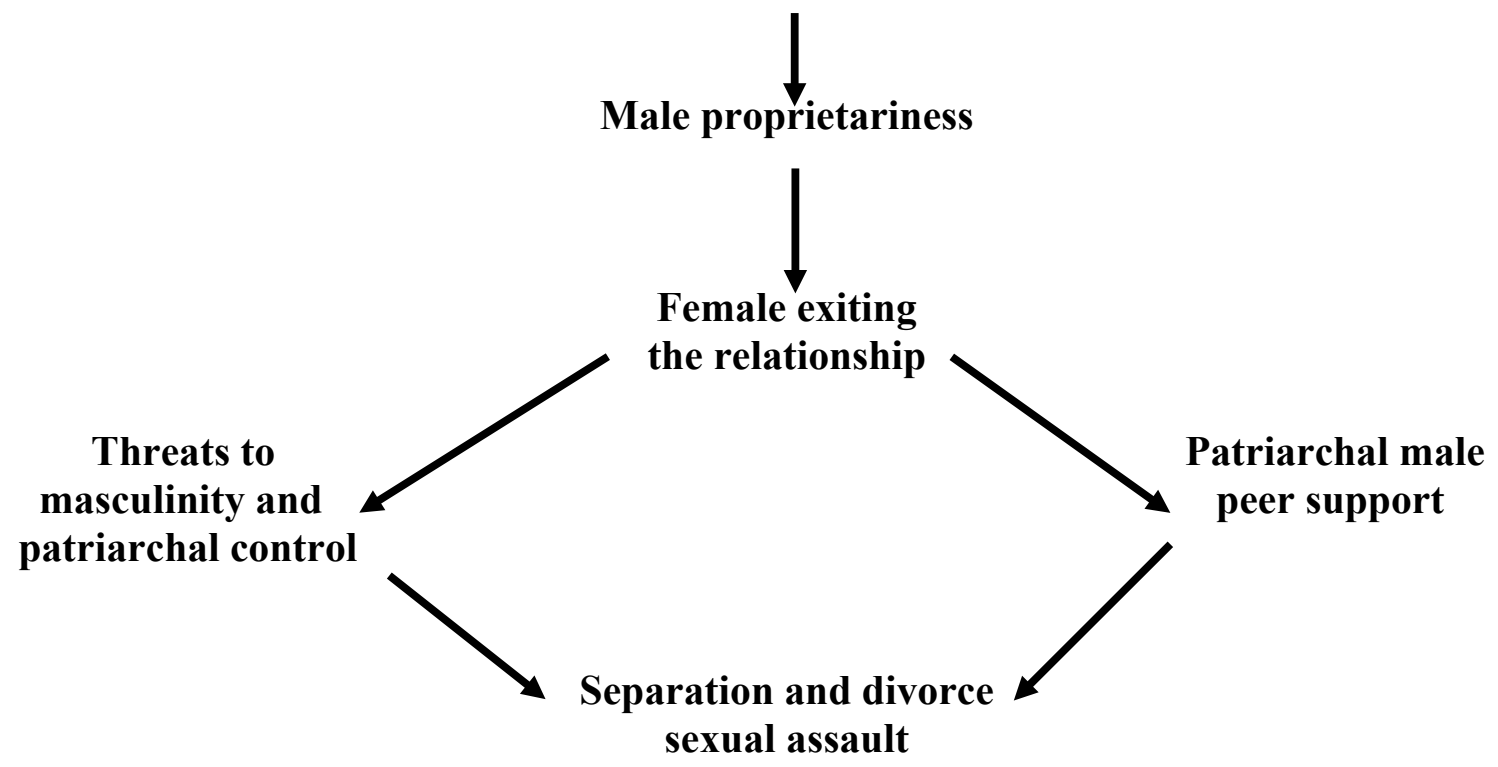

This theory is surprisingly similar in its causal thinking to primary socialization theory and civic community theory. It accounts for the contexts of violence at specific rural places within a larger socio-cultural context of patriarchy, which in turn, is conditioned by the economic and social structural transformation of rural places, especially in the United States, in the late twentieth century and into the twenty-first century. Patriarchy and male proprietariness may be defined by many feminist scholars as societal-level features, but in fact, they are actualized to varying degrees at specific places. Hence, there is variation in incidents of separation and divorce sexual assault across rural places.

\section{Links to Liepins}

The intriguing things about all three rural-based criminological theories of place and crime is that they are examples of Merton's (1957) concept of middle-range theory. They are not theories with grander designs. That is where Liepins (2000) framework of the essential elements of a community or place, without reference to any particular crime or criminal justice issue, is so valuable. Hence, Liepins it is a nominalist view of place, avoiding the deleterious effects on clear theoretical thinking from dichotomies like the global south versus the global north.

The three essential elements of the Liepins (2000) approach were spaces and structures, meaning, and practices, and their interaction with each other, hence, creating six derivative 
relationships. All three theories of the middle range include at least one of the six. Primary socialization theory (Oetting, Donnermeyer \& Deffenbacher, 1998) explicitly includes the first two, namely, meanings legitimate practices, and practices enable the circulation and challenging of meanings. That is exactly how peer networks operate to create new pro drug-using norms that are at variance with the beliefs and values expressed by school authorities, parents (most), and law enforcement. Civic community theory (Lee, 2008) embraces all six types of relationships, but especially the third (practices occur in space and through structures), the fifth (spaces and structures enable the materialization of meanings), and the sixth (meanings are embodied in spaces and structures), because his focus was on the local ecology of a community. Finally, the Feminist / Male Peer Support Model of Separation and Divorce Sexual Assault (DeKeseredy \& Schwartz, 2009) is more explicitly connected to the first (meanings legitimate practices) and the sixth (meanings are embodied in spaces and structures), even though like civic community theory, aspects of all six relationships can be discerned. ${ }^{7}$

Making explicit the connections between the three theories with rural roots and with the Liepins (2000) framework serves to illustrate how theorizing in rural criminological ought to work, at least "in theory". Liepins' (2000) framework of place provides the intellectual base on which comparative research can be conducted and/or the synthesis of literatures associated with various rural crime and criminal justice topics. These three theories of the middle range are the focus for particular topics, and even though they are more subject-matter specific, they likewise provide opportunities for rural scholars working within diverse societies and cultures around the world to link what they do with the work of others. Hence, rural criminology moves closer to its goal of internationalization.

\section{Conclusion}

If the reader has not already noticed, then it must be pointed out that all three middle-range theories originated in the United States. More western hegemony, one might assume! No, not really. All three theories were constructed with a recognition that criminological theories are urban-biased and likely cannot account for the rural realities of crime. They are 'baby' steps toward internationalizing rural criminology, despite their geographic origins.

Where does the future of rural criminological scholarship lie? I contend it is the development and continuous re-development of a theory of place that does not start with consideration of any kind of crime. Instead, adopting a more nominal approach, it sees localities as consisting of a few key elements or dimensions that form an interplay of meanings, practices and spaces/structure, from which culturally derived definitions of crime emerge based on networks of power (that is, from which is created and enforced various conceptions about what is criminal and what is not), leaving sufficient conceptual room for consideration of outside influences that may be global in scale, but continuously modify the arrangements of peoples and networks at the local level.

A framework of this type provides promise toward reaching an ideal that rural criminology can be truly international in its perspective. For this to happen, firstly the framework must be geographically neutral so that it does not make assumptions that are regionally biased, which is the problem with almost all criminological theory from the 'big four' countries. In fact, what is 


\section{The international emergence of rural criminology: Implications for the development and revision of criminological theory for rural contexts - Donnermeyer}

mostly found in the recent handbook of crime and the global south (Carrington et al, 2018) is criminologists trained in westernized forms of criminology criticizing westernized forms of criminology, as Moosavi (2019) points out in his recent review found in the British Journal of Criminology.

Second, any framework for crime and rural places also must be comparative, that is, it must allow scholars engaged in rural research to compare their results with those of other scholars at other rural places around the globe, or to set up a single research design that can account for variations in community conditions and crime at multiple research sites.

Thirdly, the framework must provide the intellectual space for integration of findings and the synthesis of literature, much as the seminal work by Weisheit, Falcone and Wells (1996) did back in 1996.

All three criteria - geographically neutral, comparative, and able to provide a platform for synthesis and integration of rural scholarship - are essential to the heuristics of any rural criminological theory. Without fulfilling these three criteria, rural criminology will either remain dominated by the "big four" countries or slide into oppositionally-expressed dichotomies of very limited intellectual value. Certainly, it will not be international.

To end on a positive note, therefore, I want readers to consider Liepins' (2000) framework of a rural community as but one example from which various middle range theories of place and crime can be derived. There should be others, perhaps not place-based, but with equal potential to provide frameworks for considering the international diversity of contexts within which rural crime are expressed can be compared and understood.

\section{Endnotes}

${ }^{1}$ This article is a revised and expanded version of a paper prepared for the Rural Crime Workshop, held at Federation University Australia (Churchill campus) on February 7-8, 2019. The author acknowledges the great help in facilitating my travel by Alistair Harkness, and of his leadership in organizing this conference. Also, I recognize the contributions of Bec Strating, Naomi Smith and Rob White, who were the conference co-organizers. Finally, I want to thank the Academy of The Social Sciences in Australia for their support of this workshop.

${ }^{2}$ There are plans to re-publish articles from volume 1, issue 1 of the International Journal of Rural Crime to the International Journal of Rural Criminology in the near future. The reason is simple: to make these articles accessible to future rural criminology scholars.

${ }^{3}$ Adopted from Liepins (2000, p. 30).

${ }^{4}$ Adopted from Oetting, Donnermeyer and Deffenbacher (1998, p. 345).

${ }^{5}$ Unlike Liepins (2000) and Oetting, Donnermeyer and Deffenbacher (1998), no schematic of casual relationships is provided by Lee (2008). Figure 4 is constructed based on Table 1 of the Lee (2008) article, which divides the independent variables into two types: control and civic 
community indicators. The dependent variables were violent crime, homicide, robbery, and aggravated assault. In Figure 4, they are referred to simply as "crime rate".

${ }^{6}$ Adopted from DeKeseredy and Schwartz (2009, pp. 31, 99).

${ }^{7}$ The reader may have noticed that only one citation each was used to describe the three middle range theories. However, there is a rich literature associated with each, and a greater network of scholars utilizing each. I encourage any reader interested in one, two or all three theories to get on Google and create a customized reading list, whether one's writing project is a paper for an undergraduate/graduate-level class, a M.S. thesis or Ph.D. dissertation, a journal article, a book chapter, or a monograph.

\section{References}

Bunei, E. (2017). Introduction to special issue on farm crime. International Journal of Rural Criminology, 3(2), 106-110. https://doi.org/10.18061/1811/81052

Bunei, E. and Barasa F.O. (2017). Farm crime victimisation in Kenya: A routine activity approach. International Journal of Rural Criminology, 3(2), 224-249. https://doi.org/10.18061/1811/81046

Bursik, R.J. (1999). The informal control of crime through neighborhood networks. Sociological Focus, 32(1), 85-97. https://doi.org/10.1080/00380237.1999.10571125

Carrington, K., Hogg, R. and Sozzo, M. (2016). Southern criminology. British Journal of Criminology, 56, 1-20. https://doi.org/10.1093/bjc/azv083

Carrington, K., Hogg, R., Scott, J. and Sozzo, M. (Eds.) (2018). The Palgrave handbook of criminology and the global south. Basingstoke, UK: Palgrave Macmillan.

https://doi.org/10.1007/978-3-319-65021-0

Ceccato, V. (2015). Rural crime and community safety. Journal of Rural Studies, 39(June), 157159. https://doi.org/10.1016/j.jrurstud.2015.04.001

Chiwona-Karltun, L., Lemenih, M., Tolera, M., Berisso, T. and Karltun, E. (2017). Crop theft and soil fertility management in the highlands of Ethiopia. International Journal of Rural Criminology, 3(2), 176-190. https://doi.org/10.18061/1811/81048

DeKeseredy, W.S. and Schwartz, M.D. (2009). Dangerous exits: Escaping abusive relationships in rural America. New Brunswick, NJ: Rutgers University Press.

Donnermeyer, J.F. (2007). Rural crime: Roots and restoration. International Journal of Rural Crime, 1, 2-20.

Donnermeyer, J.F. (2016a). Without place, is it real? International Journal for Crime, Justice and Social Democracy, 5(3), 27-40. https://doi.org/10.5204/ijcjsd.v5i3.332 
The international emergence of rural criminology: Implications for the development and revision of criminological theory for rural contexts - Donnermeyer

Donnermeyer, J.F. (2016b). Introduction to the International handbook of rural criminology. In J.F. Donnermeyer (Ed.), The Routledge international handbook of rural criminology (pp. 1-10). London, UK: Routledge. https://doi.org/10.4324/9781315755885-1

Donnermeyer, J.F. (Ed.) (2016c). The Routledge international handbook of rural criminology. London, UK: Routledge. https://doi.org/10.4324/9781315755885

Donnermeyer, J.F. (2018). The rural dimensions of a southern criminology: Selected topics and general processes. In K. Carrington, R. Hogg, J. Scott and M. Sozzo (Eds.), The Palgrave handbook of criminology and the global south (pp. 105-120). Basingstoke, UK: Palgrave Macmillan. https://doi.org/10.1007/978-3-319-65021-0_6

Donnermeyer, J.F. and DeKeseredy, W.S. (2014). Rural criminology. London, UK: Routledge. https://doi.org/10.4324/9780203094518

Harkness, A. (2017). Crime prevention on farms: Experiences from Victoria, Australia. International Journal of Rural Criminology, 3(2), 131-156. https://doi.org/10.18061/1811/81050

Harkness, A., Harris, B. and Baker, D. (Eds.). (2016). Locating crime in context and place: Perspectives on regional, rural and remote Australia. Sydney: The Federation Press.

Holmes, T. and Jones, J. (2017). Farmers' experiences as victims of crime: An exploratory study on the isle of Anglesey. International Journal of Rural Criminology, 3(2), 114-130. https://doi.org/10.18061/1811/81051

Jones, T., MacLean, B. and Young, J. (1986). The Islington crime survey: Crime, victimization, and policing in inner-city London. Brookfield, VT: Avebury Publishing Co.

Lee, M.R. (2008). Civic community in the hinterland: Toward a theory of rural social structure and violence. Criminology, 46(2), 447-478. https://doi.org/10.1111/j.17459125.2008.00115.x

Liepins, R. (2000). New energies for an old idea: Reworking approaches to 'community' in contemporary rural studies. Journal of Rural Studies, 16, 23-35. https://doi.org/10.1016/S0743-0167(99)00042-X

Lilly, J.R., Cullen, F.T. and Ball, R.A. (2015). Criminological theory: Context and consequences. Thousand Oaks, CA: Sage.

Meng, Q. (2018). Untapped scholarship: The potential of Chinese language articles to advance our knowledge of rural crime. Paper presented at the annual meeting of the American Society of Criminology, Atlanta, Georgia. November.

Merton, R.K. (1957). Social theory and social structure (revised and expanded edn.). London, UK: Collier-Macmillan.

Mills, C.W. (1959). The sociological imagination. New York, NY: Oxford University Press. 
International Journal of Rural Criminology, Volume 5, Issue 1 (November), 2019

Moosavi, L. (2019). A friendly critique of 'Asian criminology' and 'Southern criminology'. British Journal of Criminology, 59(2), 257-275. https://doi.org/10.1093/bjc/azy045

Oetting, E.R., Donnermeyer, J.F. and Deffinbacher, J.L. (1998). Primary socialization theory. The influence of community on drug use and deviance. Substance Use and Misuse, 33(8), 1629-1665. https://doi.org/10.3109/10826089809058948

Tönnies, F. (1955 [1887]). Community and society. London, UK: Routledge and Kegan Paul.

Weisheit, R. (2016). Rural crime from a global perspective. International Journal of Rural Criminology, 3(1), 5-28. https://doi.org/10.18061/1811/78047

Weisheit, R., Falcone, D. and Wells, E. (1996). Crime and policing in rural and small-town America. Long Grove, II: Waveland Press.

White, R. (n.d.) 10 obscure languages you've probably never heard spoken. Retrieved 9/11/2018 from https://www.fluentu.com/blog/obscure-languages.

Wirth, L. (1938). Urbanism as a way of life. American Journal of Sociology, 44 (1), 1-24. https://doi.org/10.1086/217913

Young, J. (2011). The criminological imagination. Cambridge: Polity Press. 